\title{
Genetic diversity and recruitment of the tropical palm, Euterpe edulis Mart., in a natural population from the Brazilian Atlantic Forest
}

\author{
R Conte $^{1}$, RO Nodari ${ }^{1}, \mathrm{R}$ Vencovsky ${ }^{2}$ and M Sedrez dos Reis ${ }^{1}$ \\ ${ }^{1}$ Departamento de Fitotecnia, Universidade Federal de Santa Catarina, C.P. 476, 88040-900 Florianópolis, SC, Brazil; ${ }^{2}$ Departamento de \\ Genética, ESALQ, Universidade de São Paulo, C.P. 83, 13400-970, Piracicaba, SP, Brazil
}

\begin{abstract}
The genetic diversity and recruitment of plants of heart-ofpalm tree (Euterpe edulis Mart.) were investigated in a natural population located in Southern Brazil. Five categories of plants, from seedlings to adults, were analysed using 16 allozymic loci. The results showed an average population level of genetic diversity $\left(H_{\mathrm{e}}=0.278\right)$ greater than the average of plant species already studied. The recruitment process of $E$. edulis is related to its genetic characteristics. A significant increase in the heterozygote frequency towards the adult stages was observed at three loci (Pgdh-2, G6pdh1 and $M d h-1)$. This suggests the possible action of natural selection in promoting such heterozygote increase. In the
\end{abstract}

same way, a linear increase in allele frequencies was observed at four loci (Prx-3, Prx-4, Pgdh-2 and G6pdh-1), indicating that recruitment is also related to a greater survival of individuals that are carriers of certain alleles. The maintenance of high diversity levels, as well as the increase in the heterozygote frequency, are positive aspects for in situ conservation. Furthermore, an increase in heterozygote frequency is favourable to the management of the species, since the maintenance of a stock of reproductive individuals with high heterozygosity levels favours the maintenance of the population dynamic and structure.

Heredity (2003) 91, 401-406. doi:10.1038/sj.hdy.6800347

Keywords: allozymes; genetic diversity; heterozygosity; recruitment; selection; management and conservation

\section{Introduction}

Heart-of-palm tree (Euterpe edulis Mart.; Arecaceae) is a native understore palm of the Brazilian Atlantic Forest, and is economically valuable because it is the main species used for palm heart extraction. This feature has caused intense exploitation since the end of 1960s, and has promoted an alteration of its natural populations. However, several studies have shown the possibility of management of this species in its natural ecosystem (Conte et al, 2000a; Reis et al, 2000a,b).

Knowledge of regeneration dynamics in natural populations and an understanding of the factors involved in recruitment are important in management systems. Such knowledge allows forecasts of the impact caused by the intervention in the forest, especially in reference to the possibility of replacement of the extracted stocks. In the case of E. edulis, replacement is dependent on the number of fruit-producing palms, as well as the process of recruitment of plants towards the subsequent stages (Conte et al, 2000b; Reis et al, 2000b).

The recruitment process is associated with different biological and nonbiological factors (Hutchings, 1997), and in the last decade some workers have also tried to relate the recruitment process to plant genetics (Eguiarte et al, 1992; Murawski and Hamrick, 1992; Tonsor et al, 1993; Alvarez-Buylla and Garay, 1994; Hossaert-McKey et al, 1996; Doligez and Joly, 1997; Lee et al, 2000). Using

Correspondence: MS dos Reis, Departamento de Fitotecnia, Centro de Ciências Agrárias, Universidade Federal de Santa Catarina, C.P. 476, 88040-900, Florianópolis, SC, Brazil.E-mail: msreis@cca.ufsc.br

Received: 15 May 2003 allozyme markers, such studies have demonstrated a heterozygote increase towards the adult stages. Furthermore, positive associations between allozyme heterozygosity and fitness have been reported (Bush and Smouse, 1991; Aravanopoulos and Zsuffa, 1998).

Allozyme markers have been considered as neutral genes reflecting evolutionary processes affecting the entire genome. However, Mitton (1994) postulates that the environment may occasionally select for allozyme markers. Moreover, classical works (Clegg and Allard, 1972; Hamrick and Allard, 1972) have shown the existence of associations among environmental factors and allele frequencies at allozyme markers. Such behaviour has also been reported by Tonsor et al (1993) and Cabin (1996), studying different life-history stages in plants. Thus, these examples appear to indicate that the recruitment process in natural populations can promote changes not only in genotype frequencies but also in allele frequencies.

In this paper, we analyse genetically the recruitment of plants of E. edulis, using allozyme markers, in a natural population from the Southern Brazilian Atlantic Tropical Forest.

\section{Materials and methods}

\section{Study site}

The study was performed in six $50 \mathrm{~m} \times 50 \mathrm{~m}$ permanent plots, in a natural population of E. edulis located in the experimental area of the São Pedro de Alcântara District, Santa Catarina (Brazil). The climate of the region is warm temperate with hot summers. According to data of 
CLIMERH/EPAGRI-SC (Government Agricultural Research Organisation for the State of Santa Catarina), the mean temperature of the study area is $20.6^{\circ} \mathrm{C}$, with a mean annual rainfall of $1565 \mathrm{~mm}$. The topography of the area is hilly, with an altitude around $300 \mathrm{~m}$ above sea level. The vegetation of the area is evergreen Atlantic Tropical Forest, and has suffered exploitation $30-40$ years ago but today it is in a stage of forest succession between intermediate and advanced.

\section{Characteristics of the species and population}

E. edulis is one of the most abundant species of the Atlantic Tropical Forest domain in Brazil. It is a monoecious species with insect-pollinated flowers (Mantovani and Morellato, 2000). Outcrossing rate estimates $\left(t_{\mathrm{m}}\right)$, based on allozyme markers, showed values approaching 1.00 (range $=0.94-1.04 ; \mathrm{SE}=0.02-0.04)$ in seven populations (Reis et al, 1998). It has high annual production of animal dispersed fruits (Reis et al, 1996; Mantovani and Morellato, 2000; Reis and Kageyama, 2000). Natural regeneration occurs from a seedling bank, which is responsible for the species dynamism in the forest (Reis et al, 1996; Conte et al, 2000b).

Data from the population studied were collected inside each plot during a period of 10 years, between 1991 and 2000. Plants of E. edulis were classified into five categories (Reis et al, 1999; Conte et al, 2000b): I - insertion height of the youngest leaf less than $10 \mathrm{~cm}$; II - insertion height from 11 to $50 \mathrm{~cm}$; III - insertion height greater than $50 \mathrm{~cm}$ and the height of exposed stem less than $1.3 \mathrm{~m}$; IV - greater than $1.3 \mathrm{~m}$ of exposed stem and nonreproductive; and $\mathrm{V}-$ reproductive plants. The demographic structure based on the five categories is represented in Figure 1.

\section{Allozyme electrophoresis}

Samples of leaf tissue were collected for allozyme analysis from approximately 70-100 individuals in each category of plants.

In total 10 enzymatic systems were used: $\alpha$-esterase $(\alpha-$ EST, EC 3.1.1.1), shikimic dehydrogenase (SKDH, EC 1.1.1.25), peroxidase (PRX, EC 1.11.1.7), 6-phosphogluconate dehydrogenase ( $P G D H$, EC 1.1.1.44), nicotinamide adenine dinucleotide dehydrogenase (NADHDH, EC 1.6.99.3), malate dehydrogenase ( $\mathrm{MDH}$, EC 1.1.1.37), phosphoglucoisomerase (PGI, EC 5.3.1.9), isocitrate dehydrogenase (IDH, EC 1.1.1.42), phosphoglucomutase (PGM, EC 5.4.2.2), and glucose-6-phosphate dehydrogenase (G6PDH, EC 1.1.1.49). Among the 10 systems employed, 16 zones with enzymatic activity were observed, revealing 11 presumed polymorphic loci. Each zone that showed a behaviour apparently independent

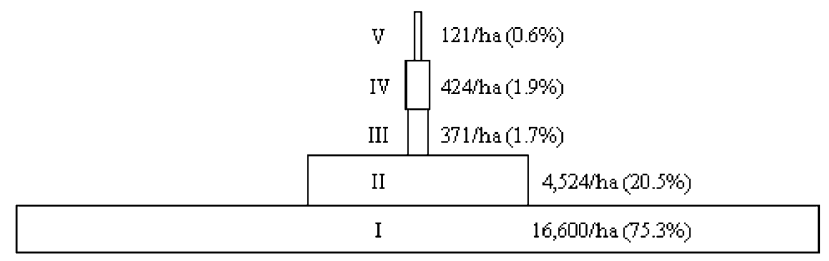

Figure 1 Demographic structure of Euterpe edulis in São Pedro de Alcântara, showing number and percentage of individuals in each category. of the others and with Mendelian segregation was considered an allozyme locus, taking into account the possible quaternary structure of each enzyme in question (Kephart, 1990).

\section{Statistical analysis}

Banding patterns (phenotypes) were scored as genotypes and transformed into allele frequencies. Levels of genetic diversity within each category were described in terms of average number of alleles per locus $(A)$, percentage of polymorphic loci $(P$; $99 \%$ criterion), observed heterozygosity $\left(H_{\mathrm{o}}\right)$, Nei's $(1978)$ expected gene diversity $\left(H_{\mathrm{e}}\right)$, and fixation index $(F)$. All of these parameters, except $F$, were calculated using BIOSYS-1 software (Swofford and Selander, 1989).

Allele frequencies for the different loci were compared among the categories of plants by the method of linear regression in $r \times 2$ tables (Cochran, 1954). The coefficient of regression (b) was tested using $\chi^{2}$ test, with one degree of freedom (Steel and Torrie, 1980). This approach allowed us to analyse changes in allele frequencies related to the process of recruitment towards the adult individuals.

Differences in the proportions between the observed number of heterozygous and homozygous individuals, among the categories of plants, were compared using a $\chi^{2}$ test for each locus (Beiguelman, 1996). In this way, it was possible to evaluate differences in the amount of observed heterozygosity among the different categories studied. Data from all loci were aggregated by summing individual $\chi^{2}$ values and their respective degrees of freedom for each locus (Workman and Niswander, 1970).

To test whether $F$-values of each category differed significantly from zero, two-tailed $\chi^{2}$ values were calculated as $\chi^{2}=F^{2} N(k-1)$, for $[k(k-1)] / 2$ degrees of freedom, where $k$ is the number of alleles and $N$ is the number of individuals sampled in each category ( $\mathrm{Li}$ and Horvitz, 1953). Furthermore, the F-values were compared among the categories to evaluate the existence of deficiency or excess of heterozygotes.

\section{Results}

\section{Allele frequencies}

Among the 16 analysed loci, five were monomorphic ( $\alpha$ Est-2, Pgdh-1, Nadhdh-1, Mdh-2, Idh-1) and 11 were polymorphic ( $\alpha$-Est-1, Skdh-1, Prx-2, Prx-3, Prx-4, Prx-5, Pgdh-2, Mdh-1, Pgi-2, Pgm-1, G6pdh-1). Two loci ( $\alpha$-Est-1 and Prx-5) showed a very low level of polymorphism, with the most frequent allele close to fixation in each category (Table 1). However, several loci showed an expressive polymorphism and similar frequencies of the most common alleles (Prx-3, Prx-4, Pgm-1, with four alleles each, and $P g d h-2$, with five alleles).

By the analysis of linear regression (Steel and Torrie, 1980), we observed significant variations in the allelic frequencies of some loci among the five categories of plants studied (Table 1). There was a significant increase in the frequency of Pr $x-3 a, \operatorname{Pr} x-3 b, \operatorname{Pr} x-4 b, \operatorname{Pg} d h-2 c$ and G6pdh-1b, towards the adult stages. On the other hand, there was a significant reduction in the frequency of the alleles Prx-3d,Prx-4a and Pgdh-2a. Allelic variation at other loci was observed, but such variation did not present a defined trend among the plant categories. 
Table 1 Allelic frequencies by categories of plants for 11 polymorphic allozyme loci

\begin{tabular}{|c|c|c|c|c|c|c|c|c|}
\hline \multirow[t]{2}{*}{ Locus } & \multirow[t]{2}{*}{ Alleles } & \multicolumn{5}{|c|}{ Categories of plants } & \multirow[t]{2}{*}{$\chi^{2}$ values } & \multirow{2}{*}{$\begin{array}{l}\text { Mean of } \\
\text { population }\end{array}$} \\
\hline & & $I$ & II & III & $I V$ & $V$ & & \\
\hline \multirow[t]{2}{*}{$\alpha$-Est 1} & $a$ & 1.000 & 0.988 & 1.000 & 1.000 & 0.995 & $0.01 \mathrm{NS}$ & 0.997 \\
\hline & $b$ & 0.000 & 0.012 & 0.000 & 0.000 & 0.005 & $0.01 \mathrm{NS}$ & 0.003 \\
\hline \multirow[t]{2}{*}{ Skdh-1 } & $a$ & 0.753 & 0.713 & 0.686 & 0.695 & 0.715 & $0.80 \mathrm{NS}$ & 0.713 \\
\hline & $b$ & 0.247 & 0.287 & 0.314 & 0.305 & 0.285 & $0.80 \mathrm{NS}$ & 0.287 \\
\hline \multirow[t]{3}{*}{$\operatorname{Pr} x-2$} & $a$ & 0.844 & 0.820 & 0.814 & 0.845 & 0.820 & $0.07 \mathrm{NS}$ & 0.830 \\
\hline & $b$ & 0.091 & 0.058 & 0.114 & 0.065 & 0.080 & $0.08 \mathrm{NS}$ & 0.080 \\
\hline & $c$ & 0.065 & 0.122 & 0.071 & 0.090 & 0.100 & $0.39 \mathrm{NS}$ & 0.090 \\
\hline \multirow[t]{4}{*}{$\operatorname{Pr} x-3$} & $a$ & 0.446 & 0.366 & 0.450 & 0.505 & 0.495 & $4.21 *$ & 0.455 \\
\hline & $b$ & 0.022 & 0.023 & 0.029 & 0.075 & 0.070 & $9.99 *$ & 0.046 \\
\hline & $c$ & 0.301 & 0.378 & 0.364 & 0.245 & 0.335 & $0.34 \mathrm{NS}$ & 0.321 \\
\hline & $d$ & 0.231 & 0.233 & 0.157 & 0.175 & 0.100 & $13.22 *$ & 0.178 \\
\hline \multirow[t]{4}{*}{$\operatorname{Pr} x-4$} & $a$ & 0.457 & 0.459 & 0.321 & 0.370 & 0.285 & $15.00 *$ & 0.379 \\
\hline & $b$ & 0.280 & 0.221 & 0.329 & 0.390 & 0.390 & $12.97 *$ & 0.325 \\
\hline & $c$ & 0.032 & 0.081 & 0.043 & 0.060 & 0.060 & 0.49 NS & 0.056 \\
\hline & $d$ & 0.231 & 0.238 & 0.307 & 0.180 & 0.265 & $0.01 \mathrm{NS}$ & 0.241 \\
\hline \multirow[t]{3}{*}{$\operatorname{Pr} x-5$} & $a$ & 0.968 & 0.971 & 0.936 & 0.985 & 0.985 & $1.57 \mathrm{NS}$ & 0.971 \\
\hline & $b$ & 0.005 & 0.023 & 0.057 & 0.015 & 0.005 & 0.09 NS & 0.019 \\
\hline & $c$ & 0.027 & 0.006 & 0.007 & 0.000 & 0.010 & $3.08 \mathrm{NS}$ & 0.010 \\
\hline \multirow[t]{5}{*}{$P g d h-2$} & $a$ & 0.575 & 0.564 & 0.536 & 0.500 & 0.470 & $5.78 *$ & 0.527 \\
\hline & $b$ & 0.091 & 0.099 & 0.100 & 0.060 & 0.105 & 0.02 NS & 0.090 \\
\hline & $c$ & 0.048 & 0.122 & 0.143 & 0.130 & 0.120 & $4.38 *$ & 0.111 \\
\hline & $d$ & 0.274 & 0.203 & 0.214 & 0.285 & 0.290 & $1.31 \mathrm{NS}$ & 0.257 \\
\hline & $e$ & 0.011 & 0.012 & 0.007 & 0.025 & 0.015 & $0.61 \mathrm{NS}$ & 0.014 \\
\hline \multirow[t]{3}{*}{$M d h-1$} & $a$ & 0.826 & 0.732 & 0.761 & 0.742 & 0.750 & $2.16 \mathrm{NS}$ & 0.762 \\
\hline & $b$ & 0.092 & 0.161 & 0.116 & 0.136 & 0.110 & $0.03 \mathrm{NS}$ & 0.123 \\
\hline & $c$ & 0.082 & 0.107 & 0.123 & 0.121 & 0.140 & $3.16 \mathrm{NS}$ & 0.115 \\
\hline \multirow[t]{3}{*}{ Pgi-2 } & $a$ & 0.640 & 0.610 & 0.664 & 0.545 & 0.585 & $2.52 \mathrm{NS}$ & 0.605 \\
\hline & $b$ & 0.355 & 0.384 & 0.329 & 0.450 & 0.395 & $1.76 \mathrm{NS}$ & 0.386 \\
\hline & $c$ & 0.005 & 0.006 & 0.007 & 0.005 & 0.020 & $1.93 \mathrm{NS}$ & 0.009 \\
\hline \multirow[t]{4}{*}{ Pgm-1 } & $a$ & 0.424 & 0.390 & 0.393 & 0.409 & 0.505 & $2.65 \mathrm{NS}$ & 0.427 \\
\hline & $b$ & 0.234 & 0.267 & 0.286 & 0.278 & 0.185 & $0.84 \mathrm{NS}$ & 0.247 \\
\hline & $c$ & 0.326 & 0.337 & 0.307 & 0.283 & 0.305 & 0.79 NS & 0.311 \\
\hline & $d$ & 0.016 & 0.006 & 0.014 & 0.030 & 0.005 & $0.00 \mathrm{NS}$ & 0.015 \\
\hline \multirow[t]{3}{*}{ G6pdh-1 } & $a$ & 0.852 & 0.894 & 0.936 & 0.895 & 0.880 & $0.59 \mathrm{NS}$ & 0.910 \\
\hline & $b$ & 0.048 & 0.100 & 0.057 & 0.105 & 0.110 & $4.31 *$ & 0.086 \\
\hline & $c$ & 0.000 & 0.006 & 0.007 & 0.000 & 0.010 & 0.85 NS & 0.004 \\
\hline
\end{tabular}

${ }^{*} P<0.05$; NS - nonsignificant.

$\chi^{2}$ values refer to the regression analysis of allelic frequencies among the five categories of plants. Allele frequecies for the population as a whole are given in the last column.

\section{Diversity indices}

From the 16 allozyme loci surveyed, 41 alleles were scored, giving an average of 2.6. $(\mathrm{SE}=0.3)$ alleles per locus, with a percentage of $62.5 \%$ of polymorphic loci (Table 2). The mean observed heterozygosity was 0.264 $(\mathrm{SE}=0.067)$ and the expected heterozygosity was estimated as $0.278(\mathrm{SE}=0.070)$. Although these results indicate a certain heterozygote deficit in the population, the mean value of the fixation index $(F=0.05)$ showed nonsignificant deviation from zero $(P>0.05)$.

At the level of categories, diversity indices from the 16 loci presented little variation (Table 2). The average number of alleles per locus ranged from 2.4 to 2.6 and the percentage of polymorphic loci ranged from 62.5 to
$68.7 \%$. The observed heterozygosity ranged from 0.242 to 0.279 and the expected heterozygosity ranged from 0.259 to 0.284 . Higher values of $H_{\mathrm{e}}$ than $H_{\mathrm{o}}$ were observed among the categories, especially in the first categories, although the $F$-values did not differ from zero.

A closer examination of the polymorphic loci at the population level (Table 2) showed quite similar results to other populations of E. edulis investigated by Reis et al (1998). The average number of alleles per polymorphic locus was $3.4(\mathrm{SE}=0.3)$, the mean observed heterozygosity was $0.423(\mathrm{SE}=0.067)$, and the expected heterozygosity was estimated as $0.445(\mathrm{SE}=0.070)$, with a fixation index of 0.049 (not significantly different from zero). By analysis at the category level, the average 
Table 2 Summary of the diversity indices for all loci (a) and polymorphic loci (b)

\begin{tabular}{|c|c|c|c|c|c|c|c|}
\hline Categories of plants & & $\mathrm{N}^{a}$ & $\mathrm{~A}^{b}$ & $\mathrm{P}^{c}$ & $\mathrm{H}_{o}^{d}$ & $\mathrm{H}_{e}^{e}$ & $\mathrm{~F}^{f}$ \\
\hline \multirow[t]{2}{*}{ I } & a & $92.9(0.1)$ & $2.4(0.3)$ & 62.5 & $0.242(0.063)$ & $0.259(0.068)$ & $0.066 \mathrm{NS}^{\mathrm{g}}$ \\
\hline & $\mathrm{b}$ & $92.8(0.1)$ & $3.3(0.3)$ & 100.0 & $0.387(0.067)$ & $0.415(0.072)$ & $0.067 \mathrm{NS}$ \\
\hline \multirow[t]{2}{*}{ II } & a & $85.6(0.3)$ & $2.6(0.3)$ & 68.75 & $0.270(0.067)$ & $0.284(0.070)$ & $0.049 \mathrm{NS}$ \\
\hline & $\mathrm{b}$ & $85.3(0.4)$ & $3.4(0.3)$ & 100.0 & $0.432(0.065)$ & $0.452(0.068)$ & $0.044 \mathrm{NS}$ \\
\hline \multirow[t]{2}{*}{ III } & a & $69.9(0.1)$ & $2.5(0.3)$ & 62.5 & $0.257(0.065)$ & $0.282(0.070)$ & $0.089 \mathrm{NS}$ \\
\hline & $\mathrm{b}$ & $69.9(0.1)$ & $3.4(0.3)$ & 100.0 & $0.411(0.064)$ & $0.451(0.068)$ & $0.088 \mathrm{NS}$ \\
\hline \multirow[t]{2}{*}{ IV } & a & $99.9(0.1)$ & $2.4(0.3)$ & 62.5 & $0.271(0.071)$ & $0.281(0.071)$ & $0.036 \mathrm{NS}$ \\
\hline & $\mathrm{b}$ & $99.8(0.1)$ & $3.2(0.3)$ & 100.0 & $0.434(0.075)$ & $0.450(0.072)$ & $0.035 \mathrm{NS}$ \\
\hline \multirow[t]{2}{*}{$\mathrm{V}$} & a & $100.0(0.0)$ & $2.6(0.3)$ & 62.5 & $0.279(0.072)$ & $0.282(0.070)$ & $0.011 \mathrm{NS}$ \\
\hline & $\mathrm{b}$ & $100.0(0.0)$ & $3.4(0.3)$ & 100.0 & $0.445(0.074)$ & $0.450(0.069)$ & $0.011 \mathrm{NS}$ \\
\hline \multirow[t]{2}{*}{ Mean of population } & a & $448.3(0.4)$ & $2.6(0.3)$ & 62.5 & $0.264(0.067)$ & $0.278(0.070)$ & $0.050 \mathrm{NS}$ \\
\hline & b & $447.8(0.6)$ & $3.4(0.3)$ & 100.0 & $0.423(0.067)$ & $0.445(0.070)$ & $0.049 \mathrm{NS}$ \\
\hline
\end{tabular}

${ }^{\mathrm{a}} N=$ mean sample size per locus. ${ }^{\mathrm{b}} A=$ average number of alleles per locus. ${ }^{\mathrm{c}} \mathrm{P}=$ percentage of polymorphic loci; $99 \%$ criterion.

${ }^{\mathrm{d}} H_{\mathrm{o}}=$ observed heterozygosity. ${ }^{\mathrm{e}} H_{\mathrm{e}}=$ expected heterozygosity (Nei, 1978). ${ }^{\mathrm{f}} \mathrm{F}=$ fixation index. ${ }^{\mathrm{g}} \mathrm{NS}=P>0.05$.

Values in parentheses are SE.

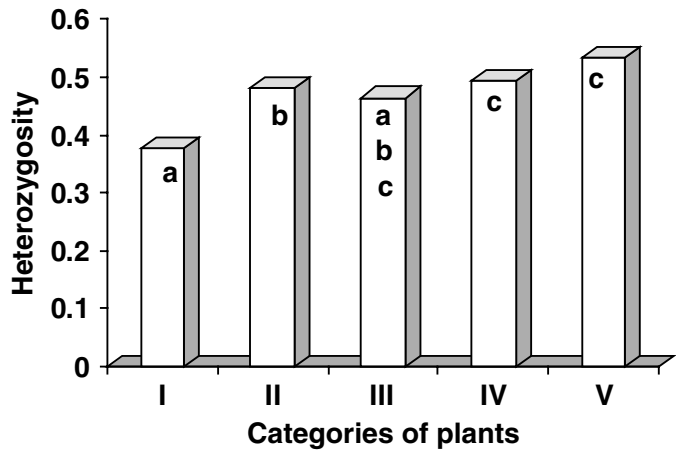

Figure 2 Mean observed heterozygosity for loci Pgdh-2, G6pdh and $M d h-1$. Different letters indicate significant differences among the categories $\left(P<0.05\right.$; based on $\chi^{2}$ test $)$.

number of alleles per locus ranged from 3.2 to 3.4. The observed heterozygosity ranged from 0.387 to 0.445 and the expected heterozygosity ranged from 0.415 to 0.452 , among the categories, while the $F$-values did not differ from zero.

An analysis of the amount of heterozygotes observed among the five categories of plants showed significant differences. Four loci were responsible for the appearance of such differences: Pr $x-5 \quad\left(\chi^{2}=9.400, P<0.05\right)$, Pgdh-2 $\quad\left(\chi^{2}=19.985, \quad P<0.01\right), \quad M d h-1 \quad\left(\chi^{2}=14.148\right.$, $P<0.01)$ and G6pdh $\left(\chi^{2}=9.553, P<0.05\right)$. With the exception of locus Prx-5, the other three loci showed significant differences between category I and most of the subsequent categories. When data from the loci Pgdh-2, Mdh-1 and G6pdh were aggregated (Figure 2), they showed a clear gradient of heterozygote increase towards Category V. The greatest heterozygosity values were found in the Categories IV and V. Although the intermediary categories did not demonstrate a defined tendency of heterozygote increase, the results suggest that the largest changes in terms of genotype frequencies must take place with the recruitment of plants in Category I, because it showed the lowest heterozygosity rate among the five categories studied.

\section{Discussion}

\section{Sources of changes in the allelic frequencies}

Results indicated that a number of polymorphic loci showed oscillations in the allelic frequencies without a defined direction among the categories. This behaviour could be related to factors such as: (i) sampling effects in the field; (ii) differences due to differential reproduction that produced the older cohorts; or (iii) genetic drift. We believe that drift is the main cause because of the high mortality rate found among the younger individuals of this species (Reis et al, 1996, 2000a; Conte et al, 2000b).

However, four loci showed significant linear alterations in the allelic frequencies among the categories of plants (Table 1). At locus Prx-3, alleles $a$ and $b$ were favoured by the recruitment process, while the frequency of allele $d$ was reduced towards the adult stage. In the same way, alleles Prx- $4 b, P g d h-2 c$ and G6pdh- $1 b$ were favoured, while the frequencies of alleles $\operatorname{Pr} x-4 a$ and $P g d h-2 a$ were reduced. There are two main hypotheses to explain the observed changes in the allelic frequencies. The first is that natural selection acts directly on the allozymic loci in such a way as to favour certain alleles in the recruitment process. The second is that linkage disequilibrium occurs, in which some allozymic loci might be linked to other loci that are under the action of natural selection. However, considering the sparse evidence of linkage disequilibrium for the allozyme markers in natural populations (Woodwark et al, 1992), the first hypothesis seems to be more appropriate to explain such a phenomenon. If it is true, it implies that some allozyme loci are not completely neutral (Bergmann and Ruetz, 1991; Mitton, 1994; Eanes, 1999; Thelen and Allendorf, 2001).

\section{Genetic diversity}

In general, a great amount of genetic diversity at both the category and the population level was observed for E. edulis (Table 2). In fact, this study revealed that the $H_{\mathrm{e}}$ value would rank this species within the top group of 
plant species already studied. An analysis of a group of 655 plant species belonging to 220 genera demonstrated an average heterozygosity of 0.150 , with $51 \%$ of polymorphic loci (Hamrick et al, 1992). For a group including only tropical tree species (38 species), Hamrick et al (1992) obtained an average heterozygosity of 0.191, with $58 \%$ of polymorphic loci. Data compiled from 12 Brazilian Atlantic Tropical Forest tree species revealed an average heterozygosity of 0.206 , with $53 \%$ of polymorphic loci (information from the authors of this paper).

An examination of the genetic diversity values obtained in the population studied also revealed a great capacity of this species to restore the levels of diversity. In fact, in spite of having been subjected to exploitation in the past, this population presents diversity levels compatible with undisturbed populations (Reis et al, 1998). The maintenance of this level of genetic diversity should allow this species to maintain its ability to adapt to novel environmental changes, mainly because of the possibility of the appearance of new recombinants in the next generations. Finally, the great homogeneity of the diversity indices among the five categories of plants suggests that the amount of adult individuals in this species is sufficient to oppose the natural loss of genetic variability by drift.

\section{Heterozygosity and plant recruitment}

As observed in the present work, many studies have reported an increase in heterozygosity towards the adult stages, as well as positive associations between heterozygosity and fitness for allozyme markers. As discussed above, allozyme markers are not completely neutral and effects of dominance and overdominance have been described (Eanes, 1999). In this aspect, inbreeding depression has been pointed out as the main cause to explain the low adaptive value of the homozygous individuals, since it can occur both in the presence of dominance or overdominance (Bush and Smouse, 1992; David, 1998; Lee et al, 2000).

The observed increase in heterozygote frequencies from small classes to adults could be generated by increased survival of the more heterozygous individuals (Eguiarte et al, 1992; Tonsor et al, 1993; Hossaert-McKey et al, 1996; Reis et al, 1998). However, heterozygote advantage constitutes only one of the possibilities to explain the increase of heterozygotes towards the adult stages (Kärkkäinen et al, 1999). In a given generation, an increase in heterozygote frequency may also be the result of selection only against one of the homozygotes. Moreover, an excess of heterozygotes can be the result of an unequal gene frequency among the parents of the population.

Linkage disequilibrium is another cause that could be used to explain heterozygote increases, in the same way as already discussed to explain changes in allelic frequencies. Such disequilibrium could generate associative overdominance between markers and background loci (Pamilo and Pálsson, 1998; Pogson and Fevolden, 1998). However, using allozyme and DNA markers, some correlation studies between growth rates and heterozygosity have shown negative evidence for the associative overdominance in natural populations (Pogson and Zouros, 1994; Thelen and Allendorf, 2001).
'Wahlund's effect' (Crow and Kimura, 1970) or the effects on observed genotype frequencies when pooling multiple, spatially differentiated subunits, could also lead to a deficiency of heterozygotes in the smaller size classes. However, this does not appear to be the case for $E$. edulis, due to the: (i) existence of overlapping generations within each category of plants studied; (ii) amount of homozygous individuals in the smaller classes was not significant; and (iii) lack of genetic structure among the six plots based on $F_{\mathrm{ST}}$ values calculated for each category of plants $\left(F_{\mathrm{ST}}\right.$-values did not differ from zero by bootstrap analysis). Moreover, the 'Wahlund's effect' was not observed in seven other E. edulis populations studied by Reis et al (1998).

Our results suggest that the 'bottleneck' for the recruitment process of $E$. edulis can be concentrated in Category I: more than $70 \%$ of the individuals that form the demographic structure of E. edulis are found in Category I (Figure 1). The mortality rate for this stage is greater than $80 \%$, suggesting that selection for adaptative traits could act in the recruitment process of those individuals. Category I of E. edulis, which represents those individuals with insertion height of the youngest leaf less than $10 \mathrm{~cm}$, corresponds to the stage with the greatest vulnerability to the factors involved in plant mortality. Thus, those individuals with a higher growth rate would have a greater opportunity to reach the adult stage. In this way, we believe that this process could be responsible for such heterozygote increases observed at some loci.

From this study, we can conclude that E. edulis possesses a great capability of restoring the levels of diversity, even after a process of exploitation. We detected levels of genetic diversity comparable with undisturbed populations of the species.

Our results provide support for the important prediction that the recruitment process of E. edulis is related to the genetic aspects of the plants. The increase in heterozygosity towards the adult stages is more concentrated in Category I. Furthermore, the linear increase in frequency of several alleles towards the adult stages appears to indicate that the recruitment process is also related to a greater survival, when the individuals are carriers of such alleles. In both cases, the results suggest that natural selection acts directly or indirectly with greater intensity on a limited number of allozyme loci.

This study also provides support for management and conservation strategies of the species. The observed genetic changes in the recruitment process, such as the heterozygote increase and the corresponding reduction of the $F$-values, are positive for in situ conservation of the species. Likewise, the increase in heterozygote frequency is favourable for management, since the maintenance of a stock of reproductive individuals with high heterozygosity levels can generate offspring with desirable genetic variability, thus conserving the dynamics and the structures of the populations.

\section{Acknowledgements}

This work was supported by CAPES and CNPq/PADCT. We thank the researchers of the Núcleo de Pesquisas em Florestas Tropicais for their assistance in the field studies, 
and also the Laboratório de Fisiologia do Desenvolvimento e Genética Vegetal for the infrastructure provided for the development of this work.

\section{References}

Alvarez-Buylla ER, Garay A (1994). Population genetic structure of Cecropia obtusifolia, a tropical pioneer species. Evolution 48: 437-453.

Aravanopoulos FA, Zsuffa L (1998). Heterozygosity and biomass production in Salix eriocephala. Heredity 81: 396-403.

Beiguelman B (1996). Curso Prático de Bioestatística. 4th edn. Sociedade Brasileira de Genética: Ribeirão Preto, SP, Brazil.

Bergmann F, Ruetz W (1991). Isozyme genetic variation and heterozygosity in random tree samples and selected orchard clones from the same Norway spruce populations. Forest Ecol Manag 46: 39-47.

Bush RM, Smouse PE (1991). The impact of electrophoretic genotype on life history traits in Pinus taeda. Evolution 45: 481-498.

Bush RM, Smouse PE (1992). Evidence for the adaptative significance of allozymes in forest trees. New Forests 6: 179-196.

Cabin RJ (1996). Genetic comparisons of seed bank and seedling populations of a perennial desert mustard, Lesquerella fendleri. Evolution 50: 1830-1841.

Clegg MT, Allard RW (1972). Patterns of differentiation in slender wild oat species Avena barbata. Proc Natl Acad Sci USA 69: $1820-1824$.

Cochran WG (1954). Some methods for strengthening the common $\chi^{2}$ tests. Biometrics 10: 417-451.

Conte R, Reis MS, Guerra MP, Nodari RO, Fantini AC (2000a). Manejo sustentado do palmiteiro (Euterpe edulis M.) na pequena propriedade catarinense. Agropec Catarin 13: 38-42.

Conte R, Reis MS, Reis A, Mantovani A, Mariot A, Fantini AC et al (2000b). Dinâmica da regeneração natural de Euterpe edulis. Sellowia 49-52: 106-130.

Crow JF, Kimura M (1970). An Introduction to Population Genetic Theory. Harper \& Row: New York.

David P (1998). Heterozygosity-fitness correlations: new perspectives on old problems. Heredity 80: 531-537.

Doligez A, Joly HI (1997). Genetic diversity and spatial structure within a natural stand of a tropical forest tree species, Carapa procera (Meliaceae), in French Guiana. Heredity 79: 72-82.

Eanes WF (1999). Analysis of selection on enzyme polymorphisms. Ann Rev Ecol Systems 30: 301-326.

Eguiarte LE, Perez-Nasser N, Piñero D (1992). Genetic structure, outcrossing rate and heterosis in Astrocarium mexicanum (tropical palm): implications for evolution and conservation. Heredity 69: 217-228.

Hamrick JL, Allard RW (1972). Microgeographical variation in allozyme frequencies in Avena barbata. Proc Natl Acad Sci USA 69: $2100-2104$.

Hamrick JL, Godt MJW, Sherman-Broyles SL (1992). Factors influencing levels of genetic diversity in woody plant species. New Forests 6: 95-124.

Hossaert-McKey MM, Valero M, Magda D, Jarry M, Cuguen J, Vernet $P$ (1996). The evolving genetic history of a population of Lathryrus sylvestris: evidence from temporal and spatial genetic structure. Evolution 50: 1808-1812.

Hutchings MJ (1997). The structure of plant populations. In: Crawley MJ (ed) Plant Ecology. 2nd edn. Blackwell Science: Oxford. pp 325-358.

Kärkkäinen K, Kuittinen H, Treuren RV, Vogl C, Oikarinen S, Savolainen O (1999). Genetic basis of inbreeding depression in Arabis petraea. Evolution 35: 1354-1365.

Kephart SR (1990). Starch gel electrophoresis of plant isozymes: a comparative analysis of techniques. Am J Bot 77: 693-712.
Lee SL, Wickneswari R, Mahani MC, Zakri AH (2000). Genetic diversity of a tropical tree species, Shorea leprosula Miq. (Dipterocarpaceae), in Malaysia: implications for conservation of genetic resources and tree improvement. Biotropica 32: 213-224.

Li CC, Horvitz DG (1953). Some methods of estimating the inbreeding coefficient. Am J Hum Genet 5: 107-117.

Mantovani A, Morellato P (2000). Fenologia da floração, frutificação, mudança foliar e aspectos da biologia floral. Sellowia 49-52: 23-38.

Mitton JB (1994). Molecular approaches to population biology. Ann Rev Ecol Systems 25: 45-69.

Murawski DA, Hamrick JL (1992). Mating system and phenology of Ceiba pentandra (Bombacaceae) in Central Panama. J Hered 83: 401-404.

Nei M (1978). Estimation of average heterozygosity and genetic distance from a small number of individuals. Genetics 89: 583-590.

Pamilo P, Pálsson S (1998). Associative overdominance, heterozygosity and fitness. Heredity 81: 381-389.

Pogson GH, Fevolden SE (1998). DNA heterozygosity and growth rate in the Atlantic Cod Gadus morhua (L.). Evolution 52: 915-920.

Pogson HG, Zouros E (1994). Allozyme and RFLP heterozygotes as correlates of growth rate in scallop Placopecten magellanicus: a test of the associative overdominance hypothesis. Genetics 137: 221-231.

Reis MS, Conte R, Fantini AC, Nodari RO (1999). Caracterização do incremento em diâmetro de Euterpe edulis Mart. e implicações para o seu manejo em formações florestais secundárias. Rev Árvore 23: 413-422.

Reis MS, Fantini AC, Nodari RO, Guerra MP, Reis A (2000a). Sustainable yield management of Euterpe edulis Martius (Palmae): a tropical palm tree from the Atlantic Tropical Forest - Brazil. J Sust Forest 11: 1-17.

Reis MS, Fantini AC, Nodari RO, Guerra MP, Reis A, Mantovani A (2000b). Management and conservation of natural populations in Atlantic rain forest: the case study of palm heart (Euterpe edulis Martius). Biotropica 32: 894-902.

Reis A, Kageyama PY (2000). Dispersão de sementes de Euterpe edulis Martius Palmae. Sellowia 49-52: 60-92.

Reis A, Kageyama P, Reis MS, Fantini AC (1996). Demografia de Euterpe edulis Martius (Arecaceae) em uma Floresta Ombrófila Densa Montana, em Blumenau (SC). Sellowia 45-48: 13-45.

Reis MS, Guerra MP, Nodari RO (1998). Management of natural populations and maintenance of genetic diversity. In: Bruns S, Mantell S, Tragardh C, Viana AM (eds) Proceedings IFS Workshop on 'recent advances in biotechnology for tree conservation and management'. Florianópolis, Brazil. pp 145-156.

Steel RGD, Torrie JH (1980). Principles and Procedures of Statistics.. McGraw-Hill: New York.

Swofford DL, Selander RB (1989). BIOSYS-1. A computer program for the analysis of allelic variation in population genetics and biochemical systematics. Release 1.7. University of Illinois, Urbana, Illinois.

Thelen GC, Allendorf FW (2001). Heterozygosity-fitness correlations in rainbow trout: effects of allozyme loci or associative overdominance? Evolution 55: 1180-1187.

Tonsor SJ, Kalisz S, Fisher J, Holtsford TP (1993). A life-history based study on population genetic structure: seed bank to adults in Plantago lanceolata. Evolution 47: 833-843.

Woodwark M, Skibinski DOF, Ward RD (1992). A study of interlocus allozyme heterozygosity correlations: implications for neutral theory. Heredity 69: 190-198.

Workman PL, Niswander JD (1970). Population studies on southwestern Indian tribes. II. Local genetic differentiation in the Papago. Am J Hum Genet 22: 24-49. 